Intern. J. Environ. Studies, 2001, Vol. 58, pp. 459-486 Reprints available directly from the publisher Photocopying permitted by license only

\title{
ECONOMIC VALUATION OF GREENHOUSE GAS EMISSIONS REDUCTION
}

\author{
MUTASEM EL-FADEL* and ELIE BOU-ZEID \\ Department of Civil and Environmental Engineering, \\ American University of Beirut (Lebanon)
}

(Received in final form 8 October 2000)

\begin{abstract}
Climate change due to greenhouse gas emissions has been at the forefront of current research efforts in the past decade. The aim of these efforts was defined at the earth summit in Rio de Janeiro as achieving "stabilization of greenhouse gas concentrations in the atmosphere at a level that would prevent dangerous anthropogenic interference with the climatic system". With on-going demographic and economic growth, stabilization of greenhouse gas emissions requires firm commitment from all countries to mitigate their emission increase often at the expense of economic growth. However, the economic and social costs of mitigating climate change are, for most countries, less than the costs of adverse impacts associated with the predicted change in climate patterns. This paper evaluates the current and future contribution of Lebanon to global greenhouse gas emissions. Mitigation options with positive or minor economic impacts are investigated. Attainable levels of emission reduction are first estimated. An economic valuation of mitigation measures associated with these levels is then performed. Reasonable emission reductions at negative costs are found to be feasible due to existing inefficiencies in the energy and industry sectors.
\end{abstract}

Keywords: GHG mitigation; Developing countries; Climate change; GHG abatement costs

\section{INTRODUCTION}

Global warming is suspected to trigger adverse environmental consequences including, coastal zones flooding and desertification. Both

*Address for correspondence: American University of Beirut, Faculty of Engineering and Architecture, 850 Third Avenue, New York, NY 10022. e-mail: mfadel@aub.edu.lb 
flooding and desertification are likely to affect the country of Lebanon since it is located at the border of desert regions and more than 60 percent of its economic activity lies in a narrow coastal plain along the Mediterranean sea [1].

The United Nations established the Framework Convention on Climate Change (FCCC) which organized negotiations between countries resulting in the Kyoto Protocol that defines the responsibility of countries in reducing GHG emissions and mitigating potential climate change [2]. Lebanon ratified the FCCC in 1994 and consequently developed a GHG emission inventory for the year 1994. The present study focuses on mitigation measures associated with high emission reduction potential and acceptable economic burdens.

Per capita GHG emissions is a good indicator to compare emissions from different countries. Table I depicts the discrepancies in emissions between developed and developing countries. Current projections indicate that developed countries will continue to emit significantly more GHG on a per capita basis than developing ones. However, total emissions from developing countries will account for nearly one-half of global emissions by 2015 [5]. Furthermore, the objective of stabilization of GHG emissions in developed countries is not expected to be attained $[3,6]$. Therefore, the probable future scenario is a continuous increase in GHG emissions from all countries with developed ones still emitting more than developing countries. However, disparities in emissions are likely to weaken.

TABLE I Population and per capita $\mathrm{CO}_{2}$ emissions in 1990 [3, 4]

\begin{tabular}{lrrlrc}
\hline Country & $\begin{array}{c}\text { Population } \\
\left(1000^{\prime}\right)\end{array}$ & $\begin{array}{c}\mathrm{CO}_{2} \text { emission } \\
(\text { tonnes/capita })\end{array}$ & Country & $\begin{array}{c}\text { Population } \\
\left(1000^{\prime}\right)\end{array}$ & $\begin{array}{c}\mathrm{CO}_{2} \text { emission } \\
(\text { tonnes/capita })\end{array}$ \\
\hline Austria & 7,712 & 7.68 & Sweden & 8,559 & 7.16 \\
Belgium & 9,972 & 11.64 & Switzerland & 6,712 & 6.71 \\
Canada & 26,522 & 17.44 & UK & 57,237 & 10.08 \\
Czech Republic & 10,362 & 16.00 & USA & 249,975 & 19.83 \\
Finland & 4,986 & 10.81 & & & \\
France & 56,440 & 6.49 & Kazakhstan & 16,598 & 13.57 \\
Germany & 79,479 & 12.76 & Ukraine & 51,334 & 12.47 \\
Iceland & 255 & 8.52 & South Africa & 35,173 & 8.80 \\
Ireland & 3,503 & 8.77 & South Korea & 42,604 & 5.13 \\
Monaco & 29 & 2.45 & Lebanon & 3,500 & 4.20 \\
Netherlands & 14,943 & 11.22 & Mexico & 84,911 & 3.66 \\
New Zealand & 3,346 & 7.61 & China & $1,129,679$ & 1.83 \\
Norway & 4,242 & 8.37 & Brazil & 147,278 & 1.47 \\
Slovakia & 5,300 & 11.00 & India & 848,632 & 0.73 \\
\hline
\end{tabular}




\subsection{The GHG Inventory for Lebanon}

The first effort to characterize GHG emissions in Lebanon was the preparation of a national inventory of GHG emissions by sources and removals by sinks for the base year 1994 . The inventory was developed using the Intergovernmental Panel on Climate Change (IPCC) reference approach [7]. Five economic sectors contributing to emissions or removal of GHG were considered including: energy, industrial processes, agriculture, land use change and forestry and waste management. Emissions from the usage of solvents and other products were not estimated in the inventory due to the lack of emission factors.

Building on this inventory, emission projection for the year 2020 and 2040 are estimated in this study. The methodologies used to estimate future emissions are sector specific. The population was assumed to grow at 2 percent per year up till 2020 then the growth rate drops to 1.5 percent per year till 2040. Gross domestic product (GDP) growth is set at 6 percent per year; however, different economic sectors have unequal development rates.

To illustrate the contribution of the various economic sectors to radiative forcing, emissions were combined as $\mathrm{CO}_{2}$ equivalent using global warming potentials (GWP) of 21 for methane and 310 for $\mathrm{N}_{2} \mathrm{O}$, as recommended by the IPCC [8]. The contribution of other gases was ignored as their emissions are relatively low and the IPCC does not specify their GWPs due to uncertainties in their radiative forcing effect. Following this approach, the energy sector including transport activities is by far the largest contributor to GHG emissions with a share of 74 percent (Fig. 1).

\subsubsection{Energy}

The main activities associated with GHG emissions from this sector include: electricity generation and energy use associated with manufacturing industries and construction, residential, commercial or institutional activities, and the agriculture/forestry/fishing sector. Base year emissions for 1994 and baseline projections for 2020 and 2040 are summarized in Table II. Projections were conducted using GDP growth and GDP/energy elasticity (Eq. (1)):

$$
E=\beta \times \mathrm{GDP}^{\alpha}
$$




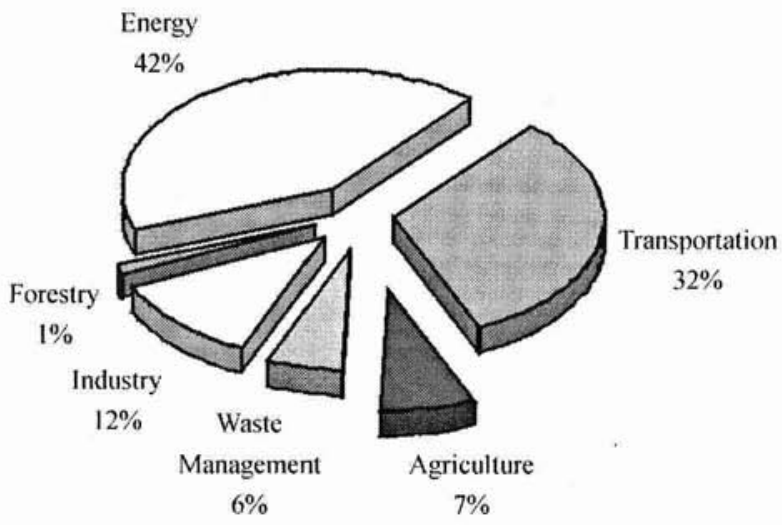

FIGURE 1 Distribution of GHG emissions by sector for 1994.

Where: $E=$ Energy demand.

$\beta=$ correlation constant.

GDP $=$ Gross Domestic Product.

$\alpha=\mathrm{GDP} /$ energy demand elasticity (dimensionless).

Units and values of $\beta$ are not needed for relative changes. Furthermore, energy efficiency and pollution control efficiency were

TABLE II GHG emissions from the energy sector ( $\mathrm{Gg} /$ year)

\begin{tabular}{lrrrrrrr}
\hline Energy emissions in 1994 & \multicolumn{1}{c}{$\mathrm{CO}_{2}$} & $\mathrm{CH}_{4}$ & $\mathrm{~N}_{2} \mathrm{O}$ & $\mathrm{NO}_{x}$ & $\mathrm{CO}$ & $\mathrm{NMVOC}^{2}$ & $\mathrm{SO}_{2}$ \\
\hline Energy industries & 3615 & 0.14 & 0.028 & 9.5 & 0.7 & 0.2 & 45.0 \\
$\begin{array}{l}\text { Manufacturing industries/ } \\
\text { construction }\end{array}$ & 2774 & 0.12 & 0.025 & 7.7 & 1.1 & 0.3 & 24.7 \\
Transport & 3957 & 1.12 & 0.035 & 34.9 & 447.2 & 83.9 & 2.7 \\
Commercial/institutional & 226 & 0.03 & 0.002 & 0.3 & 0.1 & 0.0 & 1.1 \\
Residential & 534 & 1.50 & 0.021 & 1.0 & 24.5 & 2.9 & 2.6 \\
Agriculture/forestry/fishing & 572 & 0.08 & 0.005 & 0.8 & 0.2 & 0.0 & 3.5 \\
Total 1994 & 11678 & 2.98 & 0.116 & 54.1 & 473.7 & 87.3 & 79.6 \\
Baseline scenario 2020 & 35297 & 6.95 & 0.350 & 125.9 & 1102.5 & 203.3 & 185.3 \\
Baseline scenario 2040 & 82652 & 13.30 & 0.819 & 241.2 & 2111.5 & 389.3 & 354.9
\end{tabular}

Assumptions:

GDP growth: 6 percent per year.

Energy/GDP elasticity: $0.9[1,9]$.

Baseline increase in energy efficiency: 1 percent per year [10].

Baseline increase in pollution control efficiency for $\mathrm{CO}_{2}$ and $\mathrm{N}_{2} \mathrm{O}: 0$ percent per year.

Baseline increase in pollution control efficiency for $\mathrm{CH}_{4}, \mathrm{NO}_{x}, \mathrm{CO}, \mathrm{NMVOC}, \mathrm{SO}_{2}: 1$ percent per year. 
assumed to improve as explained in Table II. Results show $\mathrm{CO}_{2}$ emissions increase by 200 and 600 percent for the years 2020 and 2040, respectively. This is relevant to overall emissions since $\mathrm{CO}_{2}$ is the major GHG released. Transport activities account for about 43 percent of GHG emissions from the energy sector. These results reflect a scenario of high development pattern. Environmental protection is effected without consideration to global issues such as climate change.

As in many developing countries, the energy use and generation in Lebanon, at present, is inefficient and has negative environmental impacts. This can be attributed to several economic and institutional factors generally encountered in developing countries [11]. The major causes in Lebanon seem to be constrained capital to finance energy efficiency measures and the lack of local expertise in implementing such measures. Most thermal plants do not use cogeneration cycles and distribution networks are in need of rehabilitation. Transportation activities are highly dependent on a fleet of low-fuel-efficiency private passenger cars. Similarly, building codes do not include energy saving specifications. In general, no attempts have been made to save on the energy bill; this inevitably leads to higher than necessary GHG emissions.

\subsubsection{Industrial Processes}

The industrial sector consists primarily of light industries and accounts for 14 percent of the GDP [1]. The main activities that contribute to GHG emissions from this sector include the production of cement, lime, asphalt, steel products, glass, chemicals and food processing. Industrial processes constitute the second most significant source of GHG emissions in Lebanon accounting for about 12 percent of total emissions.

Projection of GHG emissions for this sector can also be determined using Eq. (1). However, the total GDP is replaced by industrial activity and the industrial activity/energy elasticity is set at 0.8 since the industrial sector generally invests more in energy efficiency programs compared to the average economy. Industrial activities are expected to grow at 8 percent per year except the cement industry, which is better correlated with population growth.

Emissions estimation from the industrial sector indicates an increase in $\mathrm{CO}_{2}$ emissions of 87 and 270 percent by the years 2020 and 2040, 
TABLE III GHG emissions from the industrial processes sector $(\mathrm{Gg} /$ year $)$

\begin{tabular}{|c|c|c|c|c|c|c|c|}
\hline Industrial emissions in 1994 & $\mathrm{CO}_{2}$ & $\mathrm{CH}_{4}$ & $\mathrm{~N}_{2} \mathrm{O}$ & $N O_{x}$ & $\mathrm{CO}$ & NMVOC & $\mathrm{SO}_{2}$ \\
\hline Cement production & 1486 & - & - & - & - & - & 0.89 \\
\hline Cement production in 2020 & 1914 & - & - & - & - & - & 1.15 \\
\hline Cement production in 2040 & 2326 & - & - & - & - & - & 1.40 \\
\hline Lime production & 16 & - & - & - & - & - & - \\
\hline Asphalt industries & - & - & - & - & 0.00002 & 270.0 & - \\
\hline Glass production & 5 & - & - & - & - & 0.3 & - \\
\hline Chemical compounds & - & - & - & - & - & - & 2.36 \\
\hline Steel products & 417 & 0.078 & 0.005 & 0.01 & 0.00028 & 0.0 & 0.13 \\
\hline Food processing & - & - & - & - & - & 3.4 & - \\
\hline Total 1994 & 1924 & 0.078 & 0.005 & 0.011 & 0.00030 & 273.8 & 3.38 \\
\hline Baseline scenario 2020 & 3609 & 0.301 & 0.018 & 0.043 & 0.00116 & 1057.8 & 10.76 \\
\hline Baseline scenario 2040 & 7119 & 0.536 & 0.051 & 0.077 & 0.00206 & 1884.3 & 28.58 \\
\hline
\end{tabular}

Assumptions:

Cement industry growth $=$ population growth

Population growth 1994-2020: 2 percent per year.

Population growth 2020-2040: 1.5 percent per year.

Industrial GDP/energy elasticity: 0.8 .

Baseline increase in energy efficiency:1 percent per year [10].

Baseline increase in pollution control efficiency for $\mathrm{CO}_{2}$ and $\mathrm{N}_{2} \mathrm{O}: 0$ percent per year.

Baseline increase in pollution control efficiency for $\mathrm{CH}_{4}, \mathrm{NO}_{x}, \mathrm{CO}, \mathrm{NMVOC}, \mathrm{SO}_{2}: 1$ percent per year. 
respectively (Tab. III) with the cement industry being the largest contributor. Note that an estimated $2 \mathrm{Mg} /$ year of Hydrofluorocarbons (HFCs) were released by the industry in 1994 [12]. However, the absence of information about the exact type of HFCs prevents their inclusion in total emissions.

Note that other than improvements in energy efficiency, the control of conventional air pollutants (all gases except $\mathrm{CO}_{2}$ and $\mathrm{N}_{2} \mathrm{O}$ ) is also set at 1 percent per year. This relatively high rate is attributed to stricter pollution control measures expected in the future due to rising environmental awareness in the country. The industrial sector has been under pressure to decrease air and water industry-related pollution and manage waste safely.

\subsubsection{Agriculture}

The agriculture sector in Lebanon is geographically widespread and typically consists of single farmers working their own lands with few large agricultural companies. This, coupled with the absence of enforcement body, render regulating GHG emissions from agriculture a very difficult task. The sector contributes 10 percent to the GNP with cultivation confined to 22 percent of the country's area. GHG emissions from this sector result primarily from soils $\left(\mathrm{N}_{2} \mathrm{O}\right.$ from management of animal waste, soil nitrification/denitrification processes or fertilizer use) and field burning of agricultural residues. In addition, GHG are emitted from livestock due to enteric fermentation (methane emissions from digestion) or manure management (methane and nitrous oxide emissions).

The agricultural sector in 1994 was the third most important sector in GHG emissions. $\mathrm{N}_{2} \mathrm{O}$ emissions from this sector represent more than 99 percent of total $\mathrm{N}_{2} \mathrm{O}$ emissions in the country. Around 80 percent of emissions from this sector are attributed to agricultural soils. Projection of emissions assumed a sector growth of 2.5 percent per year [1]. Growth/emissions elasticity was set at 1 and no improvement in efficiency was included since it is unlikely that measures will be taken to reduce agricultural emissions except in the context of a GHG emission reduction program. Emissions increased by 90 and 211 percent by the years 2020 and 2040, respectively (Tab. IV). Methane and nitrous oxide emissions are the most 
TABLE IV GHG emissions from the agriculture sector ( $\mathrm{Gg} /$ year)

\begin{tabular}{lccccc}
\hline Agricultural emissions in 1994 & $\mathrm{CO}_{2}$ & $\mathrm{CH}_{4}$ & $\mathrm{~N}_{2} \mathrm{O}$ & $\mathrm{NO}_{x}$ & $\mathrm{CO}$ \\
\hline Enteric fermentation & - & 7.155 & - & - & - \\
Manure management & - & 0.822 & 0.12 & - & - \\
Residues burning & 1.05 & 0.002 & 0.00004 & 0.0015 & 0.43 \\
Agricultural soils & - & - & 2.90 & - & - \\
Total 1994 & 1.05 & 7.979 & 3.01 & 0.0015 & 0.43 \\
Baseline scenario 2020 & 2.00 & 15.162 & 5.73 & 0.0028 & 0.82 \\
Baseline scenario 2040 & 3.28 & 24.844 & 9.39 & 0.0045 & 1.34
\end{tabular}

Assumptions:

Agricultural Sector growth: 2.5 percent per year [1].

Elasticity of emissions with agricultural growth: 1 .

significant in this sector with 90 percent of $\mathrm{CH}_{4}$ emitted from enteric fermentation and 96 percent of $\mathrm{N}_{2} \mathrm{O}$ emissions from agricultural soils.

\subsubsection{Land Use Change and Forestry}

Surprisingly, in 1994, the land use change and forestry sector was a source of $\mathrm{CO}_{2}$ instead of a sink primarily because of extensive forest fires during that year. Forests are a carbon sink due to the carbon uptake that occurs during tree growth. On the other hand, they are a carbon source when the woody biomass is cut and used as fuel or when it is burned in forest fires. Forests in Lebanon cover roughly 7 percent of the country's area. Currently, the management of this important natural resource is undergoing numerous improvements [1].

Three parameters are important for the estimation of GHG emissions: woody biomass growth, use of wood from local sources, and forest area consumed by fires. Resulting emissions are summarized in Table V. Projected emissions were estimated using the IPCC methodology. In 1994, the land use change and forestry sector accounted for 1 percent of carbon emissions, which might be perceived as a minor contribution. This contribution should be compared to other countries to evaluate its significance. Land use change and forestry sectors are a net carbon sink in almost all developed countries, reducing $\mathrm{CO}_{2}$ emissions by a range of 1 percent (Netherlands) to 54 percent (Sweden) [3]. The sector is projected to become a carbon sink in the future due to improved forest fire control and forestation projects. $\mathrm{CO}_{2}$ emissions and uptake from soils are negligible because of the calcareous, non-organic nature of soils in Lebanon. 
TABLE V GHG emissions from the land use change and forestry sector $(\mathrm{Gg} / \mathrm{year})$

\begin{tabular}{|c|c|c|c|c|c|}
\hline $\begin{array}{l}\text { Forestry and land use change } \\
\text { emissions in } 1994\end{array}$ & $\mathrm{CO}_{2}$ & $\mathrm{CH}_{4}$ & $\mathrm{~N}_{2} \mathrm{O}$ & $N O_{x}$ & $\mathrm{CO}$ \\
\hline $\begin{array}{l}\text { Changes in forest and other } \\
\text { woody biomass stock }\end{array}$ & 142.5 & - & - & - & - \\
\hline Forest and grassland conversion & 58.0 & 0.25 & 0.0017 & 0.0628 & 2.21 \\
\hline Total 1994 & 200.4 & 0.25 & 0.0017 & 0.0628 & 2.21 \\
\hline $\begin{array}{l}\text { Baseline scenario } 2020 \\
\text { Baseline scenario } 2040\end{array}$ & $\begin{array}{r}-32.2 \\
-179.7\end{array}$ & $\begin{array}{l}0.08 \\
0.08\end{array}$ & $\begin{array}{l}0.0005 \\
0.0005\end{array}$ & $\begin{array}{l}0.0188 \\
0.0188\end{array}$ & $\begin{array}{l}0.66 \\
0.66\end{array}$ \\
\hline \multicolumn{6}{|l|}{ Assumptions: } \\
\hline \multicolumn{6}{|c|}{$\begin{array}{l}\text { Fruit Trees number grow by } 11 \text { percent in } 2020 \text { relative to } 1994 \text { [13]. } \\
\text { Fruit Trees number grow by } 21 \text { percent in } 2040 \text { relative to } 1994 \text { [13]. } \\
\text { Forest trees number increase } 40 \text { percent by } 2020 \text { [14]. } \\
\text { Forest trees number increase } 75 \text { percent by } 2040 \text { [14]. } \\
\text { Traditional wood use drops by } 1 \text { percent per year up till } 2020 \text { then stabilize. } \\
\text { Other wood use increase by } 0.5 \text { percent per year up till } 2020 \text { then stabilize. } \\
\text { Forest areas consumed by fires are reduced to } 30 \text { percent of the } 1994 \text { levels. }\end{array}$} \\
\hline
\end{tabular}

\subsubsection{Waste Management}

Waste management covers two major activities namely, land disposal of solid waste and wastewater treatment (domestic, commercial and industrial). The most significant GHG from the waste management sector is methane. Prediction of methane emissions was performed by projecting population, waste generation rates and management methods.

Until recently, a comprehensive approach to solid waste management in Lebanon has been virtually absent. For the year 1994, slow burning and uncontrolled dumping were still the common methods practiced for solid waste disposal. Certainly the trend is changing and there is a great deal of efforts to construct many well-controlled sanitary landfills in combination with sorting, recycling, and composting facilities [15]. Therefore, the management system used in emission estimation by the IPCC method was deep unmanaged landfills in 1994 for a portion of the waste and managed landfills in 2020 and 2040 for the greater majority of the waste.

Similar to solid waste, wastewater management has been absent particularly during the many years of civil unrest. Wastewater was typically discharged into surface water bodies such as seashores and rivers. Septic systems and land disposal were also practiced. Most new wastewater treatment plants are expected to use aerobic treatment 
processes and hence no significant methane emissions are expected in the future [12].

The amount of methane generated from solid waste was estimated at $42.8 \mathrm{Gg} /$ year in 1994 . Projections indicate that methane emissions will increase by 350 percent to $149.8 \mathrm{Gg}$ /year and by 520 percent to $222.9 \mathrm{Gg} /$ year by the years 2020 and 2040 , respectively (Tab. VI). Note that the IPCC methodology considers that $\mathrm{CO}_{2}$ emissions from waste management are primarily from the degradation of organic material derived from biomass sources (crops, forests, etc.). Hence, $\mathrm{CO}_{2}$ emissions from waste are accounted for in the land use change and agriculture sector. However, when $\mathrm{CH}_{4}$ emissions are flared to produce $\mathrm{CO}_{2}$, net emissions of $\mathrm{CO}_{2}$ from this process are reported in the waste management sector.

\subsection{Mitigating GHG Emissions}

Baseline scenario assumptions are important for the technical and economic assessment of mitigation options [16]. The projection of baseline emissions should theoretically consider emission levels if no mitigation measures specifically targeted at reducing GHG emissions are implemented. However, some baseline scenarios are set differently depending on the purpose of the study. While baseline scenario in this study was set to project emissions without GHG mitigation efforts, emission reductions with financial or environmental dividends were assumed to be partially achieved in the baseline scenario.

TABLE VI GHG emissions from the waste management sector $(\mathrm{Gg} /$ year)

\begin{tabular}{lcc}
\hline Waste management emissions 1994 & $\mathrm{CO}_{2}$ & $\mathrm{CH}_{4}$ \\
\hline Total solid waste management emissions in 1994 & - & 42.8 \\
Baseline scenario 2020 & - & 149.8 \\
Baseline scenario 2040 & & 222.9 \\
Assumptions: & \\
Population in 1994: 3.60 million [1]. & \\
Population growth 1994-2020: 2 percent per year (6 million in 2020). \\
Population growth 2020-2040: 1.5 percent per year (8.1 million in 2040). \\
Waste Generation Rate in 1994 (kg/day/capita): 0.8 (ERM, 1995, chap. 12). \\
Waste Generation Rate in 2020 (kg/day/capita): $1.34(2$ percent per year growth rate \\
from 1994). \\
Waste Generation Rate in 2040 (kg/day/capita): 1.48 (0.5 percent per year growth rate \\
from 2020). \\
No emissions from wastewater treatment (aerobic treatment is used). \\
Solid waste will be disposed of in managed sanitary landfills. \\
\hline
\end{tabular}


Mitigation efforts are aimed at reducing emissions to levels that would stabilize GHG concentrations in the atmosphere. The FCCC notes that the largest share of historical and current emissions originates from developed countries. Therefore, it states that these relatively rich countries should take the lead in mitigating adverse effects associated with climate change. On the other hand the convention points out that the share of GHG emissions originating in developing countries will inevitably grow as these nations develop their economies and raise their standard of living. Therefore, their contribution to the GHG reduction efforts is essential in the long run. In this context, potential and likely feasible mitigation measures were evaluated for the country of Lebanon (Tab. VII).

The emissions of each gas for the baseline scenarios for the year 2020 and 2040 and for the mitigation scenarios are depicted in Figure 2. Emissions are presented as percentage of the 1994 base year levels. While significant reductions can be accomplished, emissions are projected to be much higher than the 1994 emissions even in the mitigation scenarios.

\subsubsection{Energy}

Table VIII depicts mitigation scenario emissions in 2020 and 2040 for the energy sector. $\mathrm{CO}_{2}$ emissions are reduced by 30 and 38 percent in 2020 and 2040, respectively, relative to baseline scenarios for these two years. Several regulations or incentives can control energy emissions in Lebanon. Mitigation measures can target electric power generation or use, transportation and private energy consumption.

In the electricity sector, measures can target the generation and/or use trends. Simple adoption of cogeneration cycles and energy cascading can improve the efficiency of current thermal power plants from 35 to 52 percent [10]. The major electricity company, Electricité du Liban (EDL), is state-owned and adoption of any mitigation measures will undoubtedly have financial barriers. EDL is currently in deficit and most of its investments are used to rehabilitate the distribution network. On the demand side, improvements are possible due to the high price of domestic electric power in Lebanon (0.08 US\$/ $\mathrm{kWh}$ on average versus, 0.047 in Hungary, 0.071 in Mexico, and 0.046 in Poland [1]). This will encourage investments in energy-saving 
TABLE VII Mitigation options and their emission reduction potential

\begin{tabular}{|c|c|c|}
\hline Economic activity & Mitigation measures & Reduction potential relative to baseline scenario \\
\hline \multicolumn{3}{|c|}{ Energy sector } \\
\hline \multirow[t]{2}{*}{ Energy industries } & $\begin{array}{l}\text { Introduction of combined } \\
\text { power cycles ( } 50 \text { percent } \\
\text { penetration by } 2020,100 \\
\text { percent by } 2040)\end{array}$ & $\begin{array}{l}24 \text { percent by } 2020 \text { and } 48 \text { percent by } \\
2040[9,10]\end{array}$ \\
\hline & $\begin{array}{l}\text { End user efficiency } \\
\text { improvement }\end{array}$ & $\begin{array}{l}25 \text { percent by } 2020 \text { and } 40 \text { percent by } \\
2040[10]\end{array}$ \\
\hline $\begin{array}{l}\text { Manufacturing industries } \\
\text { and construction }\end{array}$ & $\begin{array}{l}\text { Improved efficiency and low } \\
\text { carbon fuel }\end{array}$ & $\begin{array}{l}7.5 \text { percent by } 2020 \text { and } 15 \text { percent by } \\
2040[10]\end{array}$ \\
\hline transport & Improved fleet technology & 30 percent by 2020 and $2040[17]$ \\
\hline Commercial/institutional & Efficiency improvement & $\begin{array}{l}25 \text { percent by } 2020 \text { and } 40 \text { percent by } \\
2040[10]\end{array}$ \\
\hline Residential & Efficiency improvement & $\begin{array}{l}25 \text { percent by } 2020 \text { and } 40 \text { percent by } \\
2040[10]\end{array}$ \\
\hline \multirow[t]{2}{*}{ Agriculture/forestry/fishing } & None & - \\
\hline & Industrial processes sector & \\
\hline \multirow[t]{2}{*}{ All industrial sectors } & $\begin{array}{l}\text { Adoption of best available } \\
\text { technology }\end{array}$ & $\begin{array}{l}25 \text { percent by } 2020,40 \text { percent by } \\
2040[10]\end{array}$ \\
\hline & Agriculture Sector & \\
\hline Enteric fermentation & none & - \\
\hline Manure management & $\begin{array}{l}\text { Improved Manure } \\
\text { Management }\end{array}$ & $\begin{array}{l}60 \text { percent of } \mathrm{CH}_{4} \text { transformed into } \\
\mathrm{CO}_{2} \text { by } 2020 \text { and } 2040\end{array}$ \\
\hline $\begin{array}{l}\text { Residues burning } \\
\text { Agricultural soils }\end{array}$ & $\begin{array}{l}\text { none } \\
\text { Improved fertilizer and } \\
\text { pesticide use }\end{array}$ & $\begin{array}{l}17 \text { percent by } 2020 \text { and } 2040 \\
\text { [10] }\end{array}$ \\
\hline
\end{tabular}


Changes in forest and other woody biomass stock

Forest and grassland conversion
Land use change and forestry sector

Conservation, reforestation, afforestation, decreased wood use

Improved forest fire

prevention and control

\section{Waste management sector}

Methane Flaring

Methane recovery
410 percent increased carbon sequestration in 2020 and 240 percent in 2040

33 percent reduction by 2020 and 2040

30 percent by 2020 and 2040

0 percent by 2020 and 40 percent by 2040 


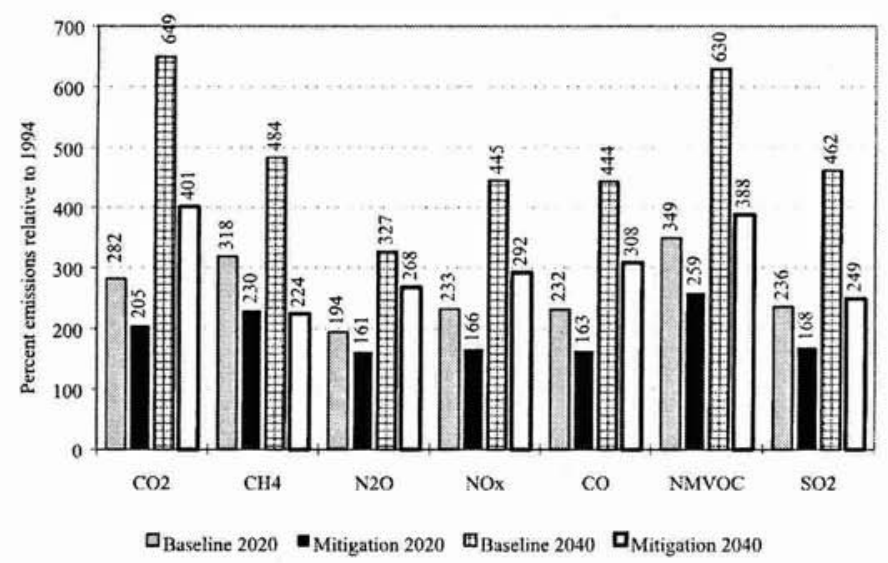

FIGURE 2 Percent variation in emissions from 1994 base levels.

TABLE VIII Mitigation scenario emissions for the energy sector $(\mathrm{Gg} /$ year)

\begin{tabular}{lcccrrrr}
\hline Energy & $\mathrm{CO}_{2}$ & $\mathrm{CH}_{4}$ & $\mathrm{~N}_{2} \mathrm{O}$ & $\mathrm{NO}_{x}$ & $\mathrm{CO}$ & $\mathrm{NMVOC}$ & $\mathrm{SO}_{2}$ \\
\hline Base year 1994 & 11678 & 3.0 & 0.12 & 54 & 474 & 87 & 80 \\
Baseline 2020 & 35297 & 6.9 & 0.35 & 126 & 1102 & 203 & 185 \\
Baseline 2040 & 82652 & 13.3 & 0.82 & 241 & 2112 & 389 & 355 \\
Mitigated 2020 & 25791 & 5.1 & 0.26 & 90 & 775 & 143 & 132 \\
Mitigated 2040 & 51459 & 8.57 & 0.52 & 158 & 1467 & 271 & 189 \\
\hline
\end{tabular}

systems and alternative energy sources which are traditionally more expensive than fossil fuel electricity. Private energy consumption can be reduced by taxes and market incentives. Currently, the governmental policy is more favorable to taxation. However, no taxes are expected to apply to industrial energy consumption because of regulations implemented to protect this sector.

Transportation activities constitute a significant GHG emitter accounting for 32 percent of total countrywide emissions. Aggressive mitigation measures that tackle traffic demand increase and technological improvements in the fleet (changes in taxation structure, inspection and maintenance programs and shifting to less energy intensive transportation modes such as public transport) can reduce emissions by 55 percent in 2020 relative to a do-nothing scenario. Simple technological fleet improvements can reduce emissions by 30 percent [17]. 


\subsubsection{Industrial Processes}

Potential mitigation measures for the industrial processes sector are diverse. The aggregate effect of a typical set of measures was estimated and adopted in this study [10]. This set includes more efficient processes, material substitution and recycling, improved motor drive systems, co-generation, and fuel switching. These mitigation measures result in 25 and 40 percent emissions reduction for the years 2020 and 2040, respectively (Tab. IX). As indicated earlier, the government is unlikely to impose costly regulations on industries to ensure their competitiveness. Instead, market incentives should be adopted to encourage industries to upgrade their processes to more efficient counterparts.

An assessment of mitigation options for the industrial sector in Lebanon concluded that emissions reduction of 40 percent relative to baseline scenario is achievable if the mitigation options assessed are applied [18]. The study indicated that most mitigation options will have negative costs. Appropriate mitigation options for Lebanon were efficient motors and lighting, efficient clean boilers and furnaces, cogeneration, and improvement in cement production.

\subsubsection{Agriculture}

Mitigation scenario emissions in 2020 and 2040 for the agriculture sector are depicted in Table $\mathrm{X}$. The share of the agriculture sector in GHG emissions is relatively small with a modest 6 percent most of which are emitted by agricultural soils. Two mitigation measures were assessed in this study: improved manure management and improved fertilizer use.

Manure could be used to produce methane for energy use on the farm with around 60 percent collection efficiency at a country level. A

TABLE IX Mitigation scenario emissions for the industrial processes sector $(\mathrm{Gg} / \mathrm{year})$

\begin{tabular}{llllllrr}
\hline Industrial processes & $\mathrm{CO}_{2}$ & $\mathrm{CH}_{4}$ & $\mathrm{~N}_{2} \mathrm{O}$ & $\mathrm{NO}_{x}$ & $\mathrm{CO}$ & $\mathrm{NMVOC}$ & $\mathrm{SO}_{2}$ \\
\hline Base year 1994 & 1924 & 0.078 & 0.005 & 0.011 & 0.0003 & 274 & 3.4 \\
Baseline 2020 & 3609 & 0.301 & 0.018 & 0.043 & 0.0012 & 1058 & 10.8 \\
Baseline 2040 & 7119 & 0.536 & 0.051 & 0.077 & 0.0021 & 1884 & 28.6 \\
Mitigated 2020 & 2706 & 0.226 & 0.014 & 0.032 & 0.0009 & 793 & 8.1 \\
Mitigated 2040 & 4271 & 0.322 & 0.031 & 0.046 & 0.0012 & 1131 & 17.1 \\
\hline
\end{tabular}


TABLE X Mitigation scenario emissions for the agriculture sector $(\mathrm{Gg} /$ year $)$

\begin{tabular}{lrrrrr}
\hline Agriculture & $\mathrm{CO}_{2}$ & $\mathrm{CH}_{4}$ & $\mathrm{~N}_{2} \mathrm{O}$ & $\mathrm{NO}_{x}$ & $\mathrm{CO}$ \\
\hline Base year 1994 & 1.05 & 8.0 & 3.01 & 0.0015 & 0.43 \\
Baseline 2020 & 2.00 & 15.2 & 5.73 & 0.0028 & 0.82 \\
Baseline 2040 & 3.28 & 24.8 & 9.39 & 0.0045 & 1.34 \\
Mitigated 2020 & 2.94 & 14.2 & 4.79 & 0.0028 & 0.82 \\
Mitigated 2040 & 4.82 & 23.3 & 7.85 & 0.0045 & 1.34 \\
\hline
\end{tabular}

systematic program should be implemented, enforced, and marketed to accomplish such collection efficiencies. Organizing educational campaigns for farmers to improve their fertilizer use habits could also reduce emissions. This is a necessary part of any fertilizer use improvement program since, as previously noted, most of agricultural activities are performed by single farmers working their own lands. However, no thorough study on the cost of such a program is available. Only estimations of potential emission reduction were made.

Another feasible mitigation measure that was not assessed in this paper is improved cattle feeding. This measure was not assessed since it is unlikely that adequate control and inspection measures will be implemented in the near future. This can be attributed to the segregated structure of cattle farming in Lebanon and to its minor contribution to GHG emissions.

\subsubsection{Land Use Change and Forestry}

Table XI illustrates mitigation scenario emissions in 2020 and 2040. Several mitigation measures are applicable for the land use change and forestry sector. They are intended to slow deforestation and assist regeneration of biomass. The deforestation trend appears to be now reversed due to increase in public awareness and it is unlikely that

TABLE XI Mitigation scenario emissions for the land use change and forestry sector (Gg/year)

\begin{tabular}{lrrrrr}
\hline Land use change and forestry & $\mathrm{CO}_{2}$ & $\mathrm{CH}_{4}$ & $\mathrm{~N}_{2} \mathrm{O}$ & $\mathrm{NO}_{x}$ & $\mathrm{CO}$ \\
\hline Base year 1994 & 200 & 0.253 & 0.002 & 0.063 & 2.21 \\
Baseline 2020 & -32 & 0.076 & 0.001 & 0.019 & 0.66 \\
Baseline 2040 & -180 & 0.076 & 0.001 & 0.019 & 0.66 \\
Mitigated 2020 & -191 & 0.050 & 0.000 & 0.013 & 0.44 \\
Mitigated 2040 & -456 & 0.050 & 0.000 & 0.013 & 0.44 \\
\hline
\end{tabular}


major deforestation activities be undertaken in the future. In addition, fire fighting capabilities are continuously improving. Reforestation projects are numerous but they are undertaken by Non-Governmental Organizations (NGOs) and hence are being conducted on a small scale. While municipalities have more resources and motives to undertake forestation programs on a larger scale, such programs have not been implemented.

Projections indicate an increase in forest tree numbers of 40 and 75 percent for the years 2020 and 2040, respectively [13]. Reforestation can increase these percentages to 50 percent by 2020 and 100 percent by 2040 . Other assumptions used in the mitigation scenarios include a constant number of fruit trees, a 2 percent per year decrease in traditional wood usage, and an 80 percent decrease in forest fires with respect to base year 1994 .

\subsubsection{Waste Management}

Waste reduction and methane recovery/flaring appear as promising options for GHG emissions reduction form the waste sector. Waste reduction was included in the baseline scenario, which curbs the growth of waste generation rates. At present and in the near future (2020), gas-to-energy projects are unlikely to be implemented due to a weak return on investment and a relative lack of local technical expertise. Flaring systems with collection efficiency of up to 80 percent could be used on new landfills and a 30 percent total flaring ratio can be accomplished in 2020 on a country basis. In 2040, methane recovery is implemented with a 40 percent recovery ratio on a country basis while flaring accounts for 30 percent of methane emissions reduction. Since the GWP of methane is 21 , the reduction in $\mathrm{CO}_{2}$ equivalent emissions is 29 and 57 percent for the mitigation scenarios of 2020 and 2040, respectively (Tab. XII).

TABLE XII Mitigation scenario emissions for the waste management sector ( $\mathrm{Gg} /$ year)

\begin{tabular}{lrrc}
\hline Waste management & $\mathrm{CO}_{2}$ & $\mathrm{CH}_{4}$ & $\mathrm{CO}_{2}$ equivalent \\
\hline Base year 1994 & 0 & 43 & 899 \\
Baseline 2020 & 0 & 150 & 3146 \\
Baseline 2040 & 0 & 223 & 4681 \\
Mitigated 2020 & 45 & 105 & 2247 \\
Mitigated 2040 & 134 & 89 & 2006 \\
\hline
\end{tabular}




\subsection{Economics of GHG Emissions Mitigation}

Estimating the cost associated with the reduction of GHG emissions remains one of the most critical components of a mitigation study. The cost is the most important factor for policy makers and hence might be the basis for any national mitigation policy. Several approaches exist to the estimation of social and economic cost of GHG abatement programs. However, most approaches fit under one of the two broad categories: top-down or bottom-up models. The fundamental difference between the two approaches is the level of aggregation of the economy. Top-down models remain at a high level and analyze major economic sectors. This allows feedback between the sectors (such as the effect of price changes in the energy sector on the industry energy intensity) to be included, and the stability and validity of the modeled economic system is assured. Bottom-up models disaggregate the economy into specific activities. This allows a more realistic assessment of technology improvements and end-user behavior. Nevertheless, economic equilibrium and consistency are not always assured and some external factors are neglected leading sometimes to over optimistic results [19].

For developing countries, and in the absence of long-term economic planning and thorough socio-economic data, the use of top-down model is often not recommended [20]. Bottom-up models offer the possibility of single sector activity projection and do not require extensive macro-economic data inputs. In this study, bottom-up evaluation of the costs associated with the 2020 and 2040 mitigation scenarios is performed.

Note that mitigation options were selected with modest or negative costs (benefits). The objective is to find no-regrets or low cost mitigation measures and assess their emissions reduction potential. Further reduction might be needed depending on the final agreements between countries at the FCCC. Financial values are reported in 1993 United States Dollars (USD). A discount rate of 10 percent is used to breakdown capital costs into yearly installment or to convert costs into 1993 equivalent values.

\subsubsection{Energy}

In the energy sector, mitigation costs were negative for all sectors except transportation (Tab. XIII). These results are not surprising in 
TABLE XIII Costs of GHG mitigation for the energy sector

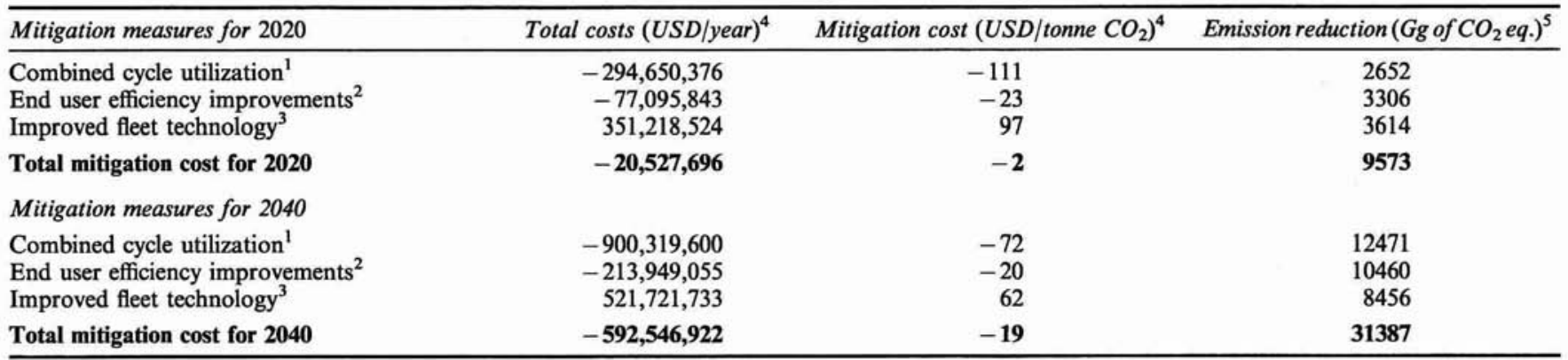

${ }^{1}$ Calculated based on energy systems costs from IPCC [18, 21], California Energy Commission [22], and German Aid Agency's Environmental Manual Software Databaser [23]. Combined cycle penetration of $50 \%$ in 2020 and $100 \%$ in 2040 . All systems are replaced at the end of their life cycle.

2 Calculated based on energy savings cost from IPCC [18] and data compilation by Shukla [19]. All systems are replaced at the end of their life cycle.

${ }^{3}$ Emission reduction and fuel savings costs based on data from study of the Lebanese transport sector emissions [17]. Costs estimated by assuming a 2000 USD increase in initial cost of cars.

${ }_{5}^{4}$ Negative cost are benefits.

${ }^{5}$ Emissions are computed by combining releases of $\mathrm{CO}_{2}, \mathrm{CH}_{4}$ and $\mathrm{N}_{2} \mathrm{O}$ with GWPs of 1,21 and 310 , respectively. 
view of the existing inefficiencies in energy production, transmission and usage in the country. Capital constraints, market imperfections and other socio-economic and investor behaviors would continue to hinder improvements in the future if no active action is implemented. On the other hand, the transport sector will not be able to cover efficiency improvement investments by the reduced operation costs.

\subsubsection{Industrial Processes}

Similarly to the energy sector, economically beneficial emission reductions in the industrial sector were found to be feasible (Tab. XIV). The same factors that hinder energy efficiency improvement in the energy sector exist in the industrial processes sector, mainly capital constraint and investor behavior. Small markets and the non-competitiveness of the industry prevent significant investments. However, benefits per tonne of $\mathrm{CO}_{2}$ avoided are considerably less than in the energy sector where public sector involvement in energy production suggests low efficiency standards compared to best available technology (BAT) present on the market.

\subsubsection{Agriculture}

Unlike the energy and industrial processes sectors, mitigating GHG emissions in the agriculture sector has positive costs (Tab. XV). Manure management is not a cost-effective measure for Lebanon, which can be attributed to the small sizes of the farms. Manure management is known to be most cost effective for large farms (more than 5000 head) where digester systems handle large amounts of manure.

Costs of improved fertilizer use could not be assessed since it might consist of a large array of measures. Very little or no studies exist assessing the costs of such measures. Only estimations of potential emission reduction were made. Costs typically cover educational campaigns for farmers and scientific research to find adequate fertilizer use patterns for local soils. Benefits are reduced total costs of fertilizers. In view of the relatively low emissions from this sector, net costs associated with such programs are not likely to be significant at the national level. 
TABLE XIV Costs of GHG mitigation for the industrial processes sector

\begin{tabular}{|c|c|c|c|}
\hline Mitigation measures for 2020 & Total costs $(\text { USD/year })^{1}$ & Mitigation cost (USD/tonne $\left.\mathrm{CO}_{2}\right)^{2}$ & Emission reduction ( $\mathrm{Gg}$ of $\mathrm{CO}_{2}$ eq. $)^{3}$ \\
\hline Typical set of measures ${ }^{4}$ & $-747,503$ & -0.83 & 905 \\
\hline \multicolumn{4}{|l|}{ Mitigation measures for 2040} \\
\hline
\end{tabular}

${ }^{1}$ Negative cost are benefits.

${ }^{2}$ Calculated on the basis of industrial GHG emissions mitigation in Lebanon [23] and a typical set of measures used in this study. All systems are replaced at the end of their life cycle.

${ }^{3}$ Emissions are computed by combining releases of $\mathrm{CO}_{2}, \mathrm{CH}_{4}$ and $\mathrm{N}_{2} \mathrm{O}$ with GWPs of 1,21 and 310 , respectively.

${ }^{4}$ The aggregate mitigation effect of several measures $[10]$. 
TABLE XV Costs of GHG mitigation for the agriculture sector

\begin{tabular}{|c|c|c|c|}
\hline Mitigation measures for 2020 & $\begin{array}{l}\text { Total costs } \\
(\text { USD/year })\end{array}$ & $\begin{array}{c}\text { Mitigation cost } \\
(\text { USD/tonne }) \mathrm{CO}_{2} \\
\end{array}$ & $\begin{array}{l}\text { Emission reduction } \\
\left(\mathrm{Gg} \text { of } \mathrm{CO}_{2} \text { eq. }\right)^{3}\end{array}$ \\
\hline $\begin{array}{l}\text { Manure management (digestion) } \\
\text { Improved fertilizer and pesticide use }\end{array}$ & $\begin{array}{l}5,325,406 \\
\text { n/a }\end{array}$ & $\begin{array}{r}284^{2} \\
\mathrm{n} / \mathrm{a}\end{array}$ & $\begin{array}{r}18.7 \\
290.3\end{array}$ \\
\hline \multicolumn{4}{|l|}{ Mitigation measures for 2040} \\
\hline $\begin{array}{l}\text { Manure management (digestion) }{ }^{1} \\
\text { Improved fertilizer and pesticide use }\end{array}$ & $\begin{array}{l}7,913,273 \\
\text { n/a }\end{array}$ & $\begin{array}{r}257^{2} \\
\mathrm{n} / \mathrm{a}\end{array}$ & $\begin{array}{r}30.7 \\
475.7\end{array}$ \\
\hline
\end{tabular}

\section{${ }^{1}$ Covered lagoon and digesters.}

${ }_{2}^{2}$ Calculated for Lebanese conditions based on construction, equipment and operation and maintenance costs [24-28].

${ }^{3}$ Emissions are computed by combining releases of $\mathrm{CO}_{2}, \mathrm{CH}_{4}$ and $\mathrm{N}_{2} \mathrm{O}$ with GWPs of 1,21 and 310 , respectively. 


\subsubsection{Land Use Change and Forestry}

Improving carbon sequestration in the land use change and forestry sector could be achieved through improved management and conservation of forests, which have environmental benefits other than GHG mitigation. These economic benefits (such as improved air quality) were not included in the assessment due to the wide variations in reported cost estimates $[29,30]$.

Table XVI depicts the costs associated with carbon sequestration in the land use change and forestry sector. Costs per tonne of $\mathrm{CO}_{2}$ are positive and vary little from 2020 to 2040 . They are relatively modest compared to the expected benefits of improved forest resources in the country.

\subsubsection{Waste Management}

Landfilling appears to be the likely waste management method that will be adopted. Landfill gas recovery systems could break even if the waste is managed properly to give a high methane yield. Such management practices might require leachate recirculation systems that accelerate waste decomposition. On the other hand, methane flaring systems have high costs compared to energy recovery. They might be adopted for small landfills since their initial cost is low.

Table XVII presents cost estimation results for the waste sector. Note that the base price of electricity was assumed to be electricity production cost at average load, which represents best the economic impacts of the mitigation measure. Base price could have been set as electricity production price at peak load, which could be as high as three times the price at base load. Under these conditions, the cost of landfill gas recovery would be a benefit of $11 \mathrm{USD}$ per tonne of $\mathrm{CO}_{2}$.

\subsubsection{GHG Abatement Cost Curves}

Development of abatement cost curves is a widely used method to report GHG mitigation costs. They consist of depicting mitigation cost per unit mass (in this study USD/tonne of $\mathrm{CO}_{2}$ ) as a function of percent reduction from baseline scenario emission levels. Abatement cost curves were developed for the mitigation study presented in this work. Mitigation measures that could not be economically assessed 
TABLE XVI Costs of GHG mitigation for the land use change and forestry sector

\begin{tabular}{|c|c|c|c|}
\hline Mitigation measures for $\mathbf{2 0 2 0}$ & $\begin{array}{l}\text { Total costs } \\
\text { (USD/year) }\end{array}$ & $\begin{array}{l}\text { Mitigation cost } \\
\left(\text { USD/tonne } \mathrm{CO}_{2}\right)\end{array}$ & $\begin{array}{l}\text { Carbon sequestration } \\
\left(\mathrm{Gg} \text { of } \mathrm{CO}_{2} \text { eq. }\right)^{3}\end{array}$ \\
\hline $\begin{array}{l}\text { Conservation, reforestation, } \\
\text { afforestation, decreased wood use }\end{array}$ & 250,700 & $1.64^{1}$ & 153.2 \\
\hline $\begin{array}{l}\text { Improved forest fire prevention and } \\
\text { control }\end{array}$ & 0 & $0^{2}$ & 6.4 \\
\hline Total mitigation cost for 2020 & 250,700 & 1.57 & 159.6 \\
\hline \multicolumn{4}{|l|}{ Mitigation measures for 2040} \\
\hline $\begin{array}{l}\text { Conservation, reforestation, } \\
\text { afforestation, decreased wood use }\end{array}$ & 442,244 & $1.64^{1}$ & 270.3 \\
\hline $\begin{array}{l}\text { Improved forest fire prevention and } \\
\text { control }\end{array}$ & 0 & $0^{2}$ & 6.4 \\
\hline Total mitigation cost for 2040 & 442,244 & 1.60 & 276.6 \\
\hline
\end{tabular}

Average carbon sequestration cost $[10,18]$.

${ }^{2}$ Forest fire control is assumed to be an integral part of forest conservation and hence its cost is not associated with GHG mitigation programs even if conservation is improved to mitigate GHG emissions.

${ }^{3}$ Emissions are computed by combining releases of $\mathrm{CO}_{2}, \mathrm{CH}_{4}$ and $\mathrm{N}_{2} \mathrm{O}$ with GWPs of 1,21 and 310 , respectively. 
TABLE XVII Costs of GHG mitigation for the waste management sector

\begin{tabular}{|c|c|c|c|}
\hline Mitigation measures for 2020 & $\begin{array}{c}\text { Total costs } \\
(U S D / \text { year })^{1}\end{array}$ & $\begin{array}{l}\text { Mitigation cost } \\
\left(\text { USD/tonne } \mathrm{CO}_{2}\right)\end{array}$ & $\begin{array}{l}\text { Emission reduction } \\
\left(\mathrm{Gg} \text { of } \mathrm{CO}_{2} \text { eq. }\right)^{3}\end{array}$ \\
\hline Methane flaring & $13,501,368^{1}$ & 15.02 & 899 \\
\hline \multicolumn{4}{|l|}{ Mitigation measures for 2040} \\
\hline $\begin{array}{l}\text { Methane flaring } \\
\text { Energy recovery }\end{array}$ & $\begin{array}{r}18,175,294^{1} \\
2,087,172^{2}\end{array}$ & $\begin{array}{r}15.85 \\
1.37\end{array}$ & $\begin{array}{l}1147 \\
1529\end{array}$ \\
\hline Total mitigation cost for 2040 & $20,262,466$ & 7.57 & 2675 \\
\hline
\end{tabular}

' Flaring cost calculated as 35 percent of recovery cost (cost of all equipment except electricity generation equipment). ${ }^{2}$ Calculated by comparing estimates of electricity generation cost from landfill gas (CEC, 1997, pp. 62-89) with price corrections to estimates of electricity production costs [1]. Average load price of electricity production is 5.5 and 5 cents/ $\mathrm{kWh}$ in 2020 and 2040 , respectively.

${ }^{3}$ Emissions are computed by combining releases of $\mathrm{CO}_{2}, \mathrm{CH}_{4}$ and $\mathrm{N}_{2} \mathrm{O}$ with GWPs of 1,21 and 310 , respectively. 


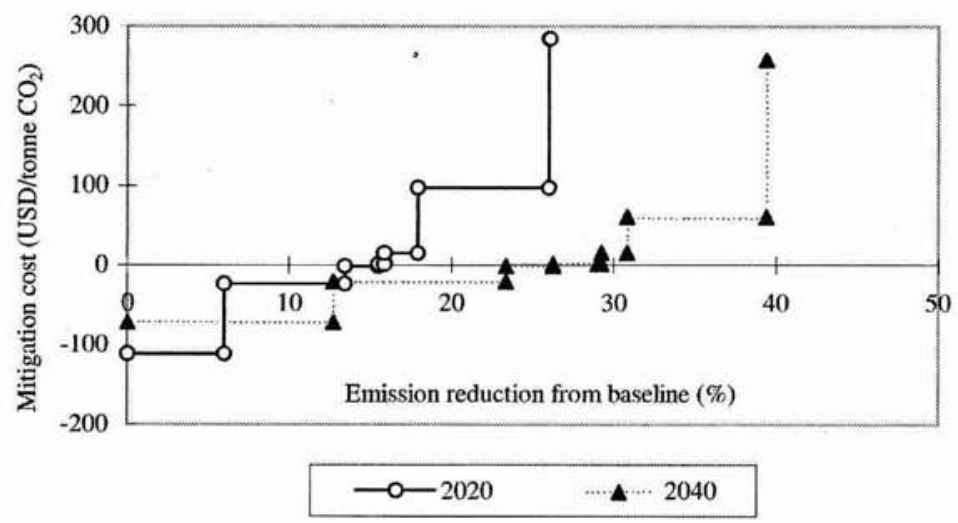

FIGURE 3 GHG abatement cost curves.

were not included. Figure 3 presents this curve for the years 2020 and 2040. Note that in 2020 up to 16 percent of the GHG reduction have negative costs and hence are economically profitable. In 2040, this percentage increases to 28 percent.

\section{CONCLUSION}

The technical and economic aspects of GHG emission mitigation in a relatively small developing country were assessed. Although emissions from Lebanon are not significant on a global scale, the collective emissions from small developing countries can reach significant levels particularly as economic growth and industrialization in these countries develop. Energy related emissions are by far the most significant accounting for more than 70 percent of total GHG emissions in 1994. Baseline emission projections predict $\mathrm{CO}_{2}$ emissions increase of 280 and 650 percent by the years 2020 and 2040, respectively. Emission reductions of 25 percent in 2020 and 40 percent in 2040 relative to baseline emissions for these two years are feasible. However, some of these reductions are associated with high economic costs such as mitigation of transport related emissions. Several mitigation measures are economically profitable and hence implementation mechanisms for them should be sought even without a GHG emission abatement program. 


\section{References}

[1] ERM (Environmental Resources Management), "Lebanon: Assessment of the State of the Environment", Technical Report, Ministry of the Environment, Beirut, Lebanon (1995).

[2] C. V. Mathai, "Global Climate Change: The Kyoto Protocol", Environmental Management Magazine (Air and Waste Management Association, February, 1998).

[3] FCCC (Framework Convention on Climate, Change), "Tables of Inventories of Anthropogenic Emissions and Removals for 1990-1995 and Projections up to 2020", United Nations, Seventh Session of the Subsidiary Body for Implementation, Bonn, Germany (1997).

[4] J. M. Buchdahl, J. W. S. Longhurst and E. J. Rowe, "An evaluation of the U.K. programme for $\mathrm{CO}_{2}$ reduction", Air Pollution Engineering and Management. Third International Conference on Air Pollution: Air Pollution 95, Computational Mechanics Publications, Southampton, UK, pp. 493-500 (1994).

[5] T. Hargrave and E. Helme, "Growth Baselines: Reducing Emissions and Increasing Investment in Developing Countries", Air and Waste Management Association's 91st Annual Meeting and Exhibition, San Diego, California, AWMA paper \#98-WP87.03 (1998).

[6] J. Sinisalo and I. Savolinen, "Stabilization of the Greenhouse Impact caused by Anthropogenic Emissions from Nordic Countries", J. the Air and Waste Management. Association 47, 806-810 (1997).

[7] IPCC (Intergovernmental Panel for Climate Change), "The Revised 1996 IPCC Guideline for National Greenhouse Gas Inventory", Reference manual (3 volumes), London, UK (1997).

[8] IPCC (Intergovernmental Panel for Climate Change), "Climate Change 1995: The Science of Climate Change", Working Group I (Cambridge University Press, Cambridge, UK, 1996).

[9] K. Halsnæs,"The economics of climate change mitigation in developing countries", Energy Policy 24, 917-936 (1996).

[10] IPCC (Intergovernmental Panel for Climate Change), "Technologies, Policies and Measures for Mitigating Climate Change", Working Group II, London, UK (1996).

[11] OECD (Organization for Economic Co-operation and Development), "Financing energy efficiency in countries with economies in transition", Annex I, Expert Group on the United Nations Framework Convention on Climate Change, Working Paper No. 6, Paris (1997).

[12] UNDP (United Nations Development Program), The First National Inventory of Greenhouse Gas Emissions by Sources and Removals by Sinks (Ministry of Environment, Beirut, Lebanon, 1998).

[13] MOA (Ministry of Agriculture), Bio-diversity Country, Study (Beirut, Lebanon, 1996).

[14] MOA (Ministry of Agriculture), Agricultural Census (Beirut, Lebanon, 1996).

[15] M. El-Fadel and W. Chahine,"An integrated solid waste management system for the Greater Beirut Area", 1st International Conference on Solid Waste, Rome, pp. $526-534$ (1999).

[16] J. C. Hourcade and J. Robinson, "Mitigating Factors: Assessing the costs of reducing GHG emissions", Energy Policy 24(10-11), 863-873 (1996).

[17] M. El-Fadel and E. Bou-Zeid, "Transportation emissions in developing countries: the case of Lebanon", Transportation Research Part D 4, 121-134 (1999).

[18] N. Ghaddar and T. Mezher, "Modeling of current and future energy intensity and greenhouse gas emissions of the Lebanese industrial sector: assessment of mitigation options", Applied Energy 63, 53-74 (1999).

[19] P. R. Shukla, "Greenhouse Gas models and abatement costs for developing nations", Energy Policy 23(8), 677-687 (1995). 
[20] IPCC (Intergovernmental Panel for Climate Change), "Climate Change 1995: Economic and Social Dimensions of Climate Change", Working Group III (Cambridge University Press, Cambridge, UK, 1996).

[21] IPCC (Intergovernmental Panel for Climate Change), "Climate Change 1995: Impacts, Adaptation and Mitigation of Climate Change, Scientific-Technical Analyses", Working Group II (Cambridge University Press, Cambridge, UK, 1996).

[22] CEC (California Energy Commission), 1996 Energy Status Report-Report Summary (CA 1997).

[23] GTZ (Gesellschaft fur Technische Zusammenarbeit), Environmental Manual Software (Deutsche GmbH, Energy and Transport Division, Eschborn, Germany, 1996).

[24] ASAE (American Society of Agricultural Engineers), "Manure Production and Characteristics", ASAE Data: ASAE D384.1. St. Josephs, MI (1988).

[25] USEPA (United States Environmental Protection Agency), "Options for Reducing Methane Emissions Internationally", - Report to Congress K. B. Hogan (Ed.). (EPA 430-R-93-006, 1993).

[26] USEPA (United States Environmental Protection Agency), "Opportunities to Reduce Anthropogenic Methane Emissions in the United States", Report to Congress (EPA 430-R-93-012, 1993).

[27] U. Marchaim, "Biogas Processes for Sustainable Development", FAO Agricultural Services Bulletin 95, NY (1992).

[28] L. M. Safley and P. W. Westerman, "Biogas Production from Anaerobic Lagoons", Biological Wastes 23, 181-193 (1988).

[29] K. Halsnæs, J. M. Callaway and H. J. Meyer, "Economics Greenhouse Gas Limitations: Methodological Guidelines", United Nations Environment Program Collaborating Center on Energy and Environment (Risø National Laboratory, Denmark, 1998).

[30] OECD (Organization for Economic Co-operation and Development), "Full Cost Pricing", Working Paper No. 3, Annex I Expert Group on the United Nations Framework Convention on Climate Change, Paris, France (1997). 